\title{
Experimental Studies on Punching Shear and Impact Resistance of Steel Fibre Reinforced Slag Based Geopolymer Concrete
}

\author{
Srinivasan Karunanithi \\ SCALE, VIT University, Vellore, Tamil Nadu, India \\ Correspondence should be addressed to Srinivasan Karunanithi; srinivasan.k@vit.ac.in
}

Received 3 February 2017; Accepted 12 March 2017; Published 22 March 2017

Academic Editor: Peng Zhang

Copyright ( 2017 Srinivasan Karunanithi. This is an open access article distributed under the Creative Commons Attribution License, which permits unrestricted use, distribution, and reproduction in any medium, provided the original work is properly cited.

\begin{abstract}
The study was focused on slag based geopolymer concrete with the addition of steel fibre. The slag based geopolymer concrete was under shear load and sudden impact load to determine its response. The punching shear represents the load dissipation of the material and the energy absorption capacity of the geopolymer concrete to impact load. The various percentage of steel fibre in the slag based geopolymer concrete was $0.5 \%, 1.0 \%$, and $1.5 \%$. Overall the dosage $0.5 \%$ of steel fibre reinforced slag based geopolymer shows better results with a punching shear of $224 \mathrm{kN}$ and $1.0 \%$ of steel fibre incorporated geopolymer concrete had the better energy absorption capacity with $3774.40 \mathrm{~N} \cdot \mathrm{m}$ for first crack toughness and $4123.88 \mathrm{~N} \cdot \mathrm{m}$ for ultimate failure toughness.
\end{abstract}

\section{Introduction}

The paper investigates the flexural behaviour of shallow reinforced concrete beams strengthened with high strength steel cord and carbon fibre reinforced geopolymers, cured at room temperature. The flexural behaviour was assessed by means of four-point bending test. Two beam specimens for each system (i.e., steel cord and carbon fibre reinforcement) and one unstrengthened control beam were casted and tested by Menna et al. [1]. The passivating capacity of synthetic specimens with three various fly ash mortars treated with three activators and the stability of the passive state under the effect of $0 \%, 0.2 \%, 0.4 \%$, and $2 \%$ chloride accompaniments relative to the binder material, in an environment of seemingly constant humidity, and in humidity cycles were analysed.

The development with time of corrosion potential $\left(E_{\text {corr }}\right)$ and polarisation resistance $\left(R_{p}\right)$ was calculated. Polarisation curves and time constants $(s)$ were also measured for specimens using little period galvanostatic pulses [2]. The predicted and the experimental pullout curves were determined for all the circumstances for firing and testing temperatures. The friction coefficient effects, the fibre Young's modulus, and concrete rupture strength and the testing temperature on the pullout performances were showing high performance [3]. The addition of ceramic fibre to plain concrete has considerably increased its properties, dynamic strength, critical strain, and energy absorption [4].

Multiwalled Carbon Nanotubes (MWCNTs) fibres in the concrete studied in the range 0.1 to $0.5 \%$ by weight and fibres are poorly dispersed and strictly agglomerated in $1 \%$ of concrete weight. MWCNT improves Young's modulus, flexural strength, and flexural toughness by as much as $160 \%, 109 \%$, and $275 \%$, respectively. It also boosted the fracture energy and increased the electrical conductivity by $194 \%$ [5]. Addition of carbon fibres in geopolymer concrete improves its electrical conductivity and the electrical resistance of concrete analysed through AC-impedance spectroscopy [6]. Impact strength and compressive strength were determined for the concrete added with carbon fibre from $0 \%$ to $1 \%$ by weight of concrete. The $0.5 \%$ of carbon fibre was the optimum dosage that performed well in mechanical properties compared to the other ratios [7].

The spherical shape of fly ash can increase the extrudability of geopolymer mixture, followed by the denser and compact microstructure of the finial geopolymeric boards with low percentage of fly ash. However, when excess fly ash was added, the enhancement of the microstructure caused by fly ash cannot reward the reduction of geopolymer because of the low pozzolanic reactivity of fly ash in situation of 
high percentage of binder. So, the microstructure of fly ashgeopolymer boards was loosely packed [8]. Nazari et al. studied the flexural strength of unreinforced and reinforced condition with Boroaluminosilicate as binder. They achieved high flexural strength of $9.5 \pm 0.4$ for unreinforced still high strength and $11.8 \pm 0.9$ for the reinforced condition. The high strength of the reinforced condition is due to bond between steel fibres and geopolymer in the presence in Boroaluminosilicate binder. Further it is found that spherical shape of fly ash has an influence on concrete and increases the extrudability of geopolymer mixture. It results in dense and compact microstructure of concrete matrix [9].

A torsional behaviour of steel fibre reinforced concrete (SFRC) beam samples was studied by using the current analytical models and the suggested approaches. The linear strain distribution across the effective thickness of shearflow zone, which has been normally expected in the analysis of reinforced concrete or SFRC torsional members, is also evidently detected through the torsional tests on the SFRC beams and well assessed by the suggested models. The COV (coefficient of variation) values were $9.1 \%$ and $10.4 \%$, respectively. First modelling provided the maximum accuracy in estimating their ultimate torsional strengths, and second modelling shows the better simulation results on their torsional behaviour [10].

The stress-strain curves of concrete under the various impact loads. The results show the effect of the strain rate and the impact resistance of concrete [11]. The addition of ceramic fibre for $0.1 \%$ and $0.2 \%$ in concrete performed the considerable increase in the dynamic strength and elastic modulus of concrete [12]. The various types of fibres were used in concrete with different percentage like cellulose $(0.15 \%)$, ppolypropylene $(0.15 \%)$, and steel fibre $(0.50 \%)$. The significant impact strength was attained by the concrete with steel fibre [13]. The fibre addition of $2.4 \%$ in concrete has increased the postcrack energy of $2.98 \mathrm{~J}$. The improvement in the flexural and impact resistance of the concrete was due to the discontinuous fibre distribution. Around $38.5 \%$ of strength increase was observed for fibre concrete compared to reference concrete [14].

The $65 \%$ strain rate and energy absorption of concrete were improved when the BFRGC (Basalt Fibre Reinforced Geopolymeric Concrete) was used in concrete. $0.3 \%$ of optimum volume of fibre in concrete shows the improvement of $8.9 \%$ of specific energy absorption for geopolymer concrete [15].

\section{Materials and Experimental Methods}

2.1. Slag. The Ground Granulated Blast Furnace Slag was used as binder of geopolymer concrete production. It is an industrial by-product that was supplied by Ferrosilicon manufacturing firm and the various properties of the slag were shown in Table 1 conforming to BS 6699-1992 (British Standard) [16].

2.2. Fine Aggregate. Fine aggregate (river sand) used in the study was passing through $4.75 \mathrm{~mm}$ IS sieve, conforming to
TABLE 1: Physical and chemical properties of slag.

\begin{tabular}{lc}
\hline Observation & Slag \\
Colour & White \\
\% passing through 45 -micron sieve (wet sieving) & 91.35 \\
Specific gravity & 2.86 \\
Blaine's fineness $\left(\mathrm{m}^{2} / \mathrm{kg}\right)$ & 415 \\
$\mathrm{SiO}_{2}$ & 37.3 \\
$\mathrm{Al}_{2} \mathrm{O}_{3}$ & 11.48 \\
$\mathrm{Fe}_{2} \mathrm{O}_{3}$ & 0.23 \\
$\mathrm{CaO}$ & 42.47 \\
$\mathrm{MgO}$ & 7.32 \\
$\mathrm{SO}_{3}$ & 1.2 \\
$\mathrm{Moisture} \mathrm{content}$ & $10-13 \%$ \\
\hline
\end{tabular}

TABLE 2: Sieve analysis of river sand.

\begin{tabular}{lcc}
\hline Serial number & Sieve size $(\mathrm{mm})$ & Cumulative\% of river sand \\
\hline 1 & 4.75 & 96.60 \\
2 & 2.36 & 95.70 \\
3 & 1.18 & 69.60 \\
4 & 0.6 & 19.70 \\
5 & 0.3 & 5.20 \\
6 & 0.15 & 1.30 \\
7 & 0.075 & 0.10 \\
8 & Pan & - \\
\hline
\end{tabular}

grading zone-II of IS 383-1997 [17]. The specific gravity of the fine aggregate was 2.65 . The grain size of river sand is shown in Table 2.

2.3. Coarse Aggregate. Gravel pieces which passed $12.5 \mathrm{~mm}$ sieve size, retained on $10 \mathrm{~mm}$ sieve, were used as coarse aggregate for concrete production, conforming to IS 383-1997 [17]. The specific gravity of the coarse aggregate was 2.73 .

2.4. Alkali Activators and Chemical Admixtures. The alkali activator used in the study was sodium hydroxide solution prepared for 12 molarity concentration. The accelerator like calcium nitrate $1 \%$ and sodium sulfate of $10 \%$ of the weight of slag is also used in the concrete. For the improvement of workability, the high range water reducer was used as well as accelerator based superplasticizer (CERA-ACCL) at $1.5 \%$ by weight of slag.

2.5. Fibre Reinforcement. Glued steel fibres of $35 \mathrm{~mm}$ length and $0.5 \mathrm{~mm}$ diameter with an aspect ratio of 70 were added in geopolymer concrete at dosages of $0.5 \%, 1.0 \%$, and $1.5 \%$. The effects of steel fibre for different dosage of reinforcements were investigated in slag based geopolymer concrete in the slab-column junction setup. The properties of steel fibre are given in Table 3.

2.6. Curing Regime. An accelerated curing using hot air oven and steam curing was provided for the fresh geopolymer mixes. The specimens were cured in hot air oven curing at 
TABLE 3: Properties of glued steel fibres (SF).

\begin{tabular}{lcccccc}
\hline Fibre type & Length $(l)(\mathrm{mm})$ & Diameter $(d)(\mathrm{mm})$ & $l / d$ ratio & Failure strain $(\%)$ & Tensile strength $(\mathrm{MPa})$ & Relative density $\left(\mathrm{kN} / \mathrm{m}^{3}\right)$ \\
\hline SF & 35 & 0.5 & 70 & 3.2 & 1721 & 7.65
\end{tabular}

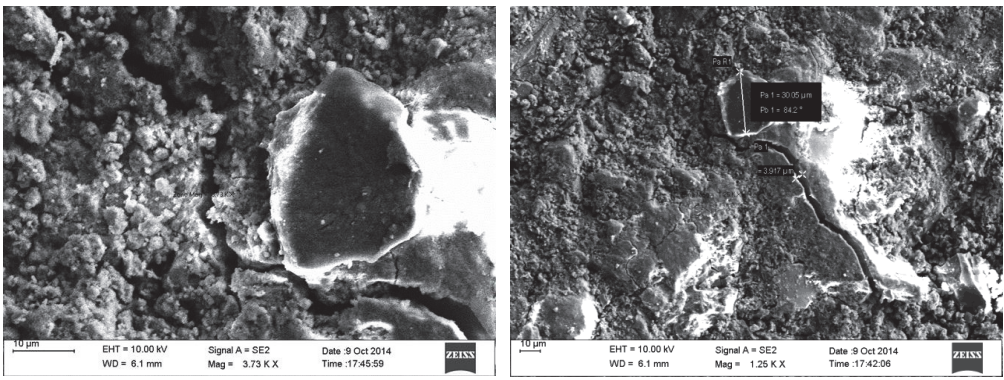

FIGURE 1: Scanning electron microscope image of slag in $10 \mu \mathrm{m}$ magnification.

$100^{\circ} \mathrm{C}$ for 6 -hour duration and a steam chamber curing at $75^{\circ} \mathrm{C}$ for 6 -hour duration was used for curing the specimens. Later, the geopolymer specimens were remoulded and kept in ordinary room temperature $\left(37^{\circ} \mathrm{C} \pm 2^{\circ} \mathrm{C}\right)$ and specimens are tested.

\section{Experimental Methods}

3.1. SEM and EDX Analysis. The scanning electron microscope (SEM) images were taken for the slag based geopolymer samples with alkali activators and accelerators. The concrete mix GC2 consists of Binder to Total Aggregate ratio (B/TA) of 0.22 and Fine Aggregate to Coarse Aggregate ratio (FA/CA) of 0.6 with Sodium Hydroxide $(12 \mathrm{M})$. The test samples were prepared as powder and sample was kept stub for sputter coating machine in which the gold coating was applied. The gold coating helped for the conductivity between the samples and stubs in getting the image in the scanning electron microscope.

The SEM images, shown in Figures 1 and 2, have the same pattern of an image in the $2 \mu \mathrm{m}$ magnification. From the SEM image, the constituents which present in concrete are well agglomerated. The kind of agglomeration load is due to the presence of minerals such as Magnesium $(\mathrm{Mg})$, Sodium $(\mathrm{Na})$, calcium $(\mathrm{Ca})$, and silica $(\mathrm{Si})$ (Bastidas et al.) in the binder. Further the agglomeration is due to the dissolution of sodium irons with silica and alumina atoms form crystals. The formation of minerals and ions represents the threedimensional alumina-silicate gel. The microstructure shows the formation of calcium, silicate, and alumina which forms the microcrystal. The key reason of formation of crystalline structure in the sample is because of the presence of calcium and silica in the slag. The formation of crystal makes ample addition to the density of binder. The SEM images for the various particle size are shown in Figures 1 and 2. These SEM images show the microstructures of the test samples with range of particle sizes. The particle size found in the samples is varying from $1.361 \mu \mathrm{m}$ to $6.102 \mu \mathrm{m}$. The resistance towards bearing the pressure and energy absorption of the geopolymer was amply improved by the increase in density
TABLE 4: Presence of elements in EDX analysis.

\begin{tabular}{lcccc}
\hline Element & Weight (\%) & Atomic (\%) & Compound (\%) & Formula \\
\hline $\mathrm{C}$ & 1.74 & 3.19 & 6.36 & $\mathrm{CO}_{2}$ \\
$\mathrm{Na}$ & 9.46 & 9.09 & 12.75 & $\mathrm{Na}_{2} \mathrm{O}$ \\
$\mathrm{Mg}$ & 2.67 & 2.43 & 4.43 & $\mathrm{MgO}$ \\
$\mathrm{Al}$ & 5.19 & 4.25 & 9.82 & $\mathrm{Al}_{2} \mathrm{O}_{3}$ \\
$\mathrm{Si}$ & 12.38 & 9.73 & 26.48 & $\mathrm{SiO}_{2}$ \\
$\mathrm{~S}$ & 0.79 & 0.54 & 1.96 & $\mathrm{SO}_{3}$ \\
$\mathrm{~K}$ & 1.55 & 0.88 & 1.87 & $\mathrm{~K}_{2} \mathrm{O}$ \\
$\mathrm{Ca}$ & 25.97 & 14.31 & 36.34 & $\mathrm{CaO}^{2}$ \\
$\mathrm{O}$ & 40.25 & 55.57 & - & - \\
\hline Total & 100 & - & - & - \\
\hline
\end{tabular}

by the microcrystal structure formation. The density of gel formation was cumulative improving the structure of mortar in the geopolymer concrete.

The Energy-Dispersive X-ray spectroscopy (EDX) analysis was also carried out on the hardened slag based geopolymer paste samples and is shown in Figure 3. The EDX shows the presence of the elements and its percentage present in each sample; the presence of various elements and its percentage are shown in Table 4 . The presence of $\mathrm{CaSiO}_{3}$ was confirmed and the atomic weight of the major minerals is as follows: Calcium $(\mathrm{Ca})=14.31$ and silica $(\mathrm{Si})=9.73$ and the remaining are contents in the Oxide $(\mathrm{O})=55.57$. This was taken from the test samples that are used for the SEM analysis.

The EDX results of samples show the presence of high percentage of calcium $(\mathrm{Ca})$, Silicate $\left(\mathrm{SiO}_{2}\right)$, and oxides. So the result represents the presence of Wollastonite $\left(\mathrm{CaSiO}_{3}\right)$. Each test sample showed the same range of atomic weight and it contains the Magnesium, Sodium, Aluminum, Potassium, and sulfate in the minor quantity. The presence of the Sodium and sulfate in the samples was due to the alkali activators and accelerators.

3.2. Punching Shear Test. The specimen was prepared as the junction of column and slab. The curing regime for 

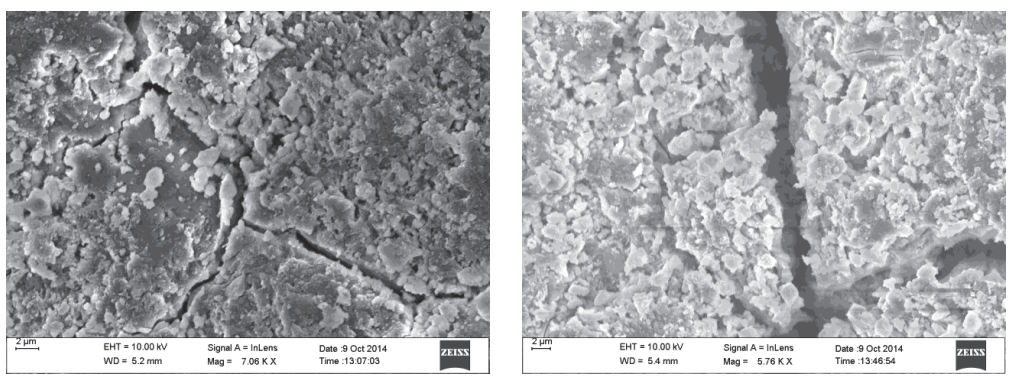

FIGURE 2: Scanning electron microscope image of slag in $2 \mu \mathrm{m}$ magnification.

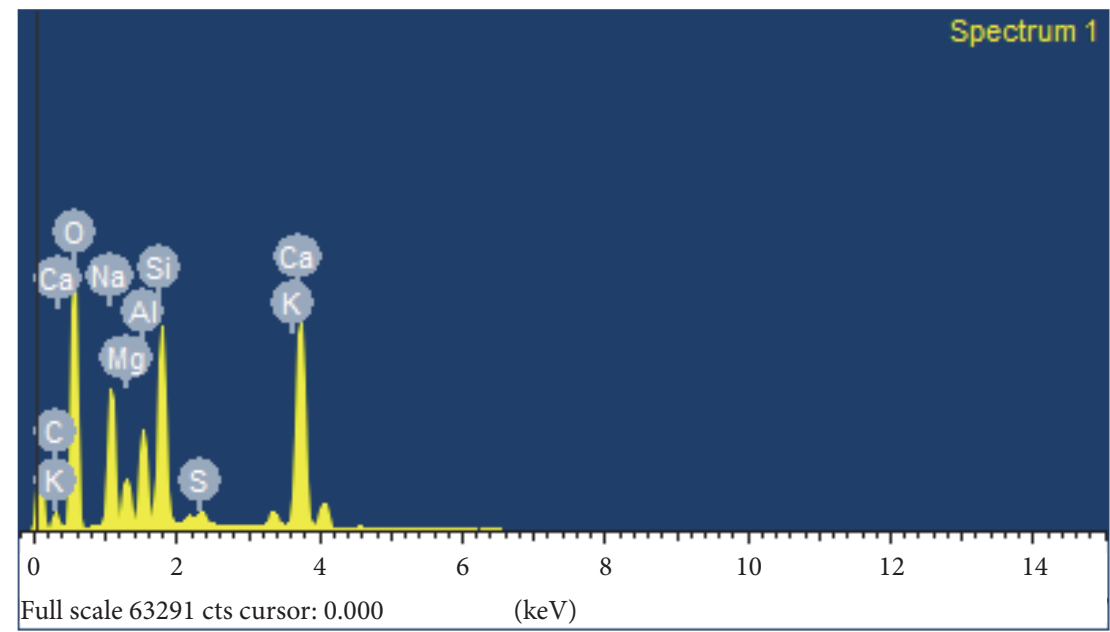

Figure 3: Measurement of the elements present in the sample by EDX analysis.

the slag based steel fibre reinforced geopolymer concrete specimens will be in hot air oven at a temperature of $100^{\circ} \mathrm{C}$ for 6 hours and in the accelerated curing called steam chamber curing for $75^{\circ} \mathrm{C}$ for 6 hours. This type of curing will provide the heat air with the moisture. The moisture air will not lead to the surface micro crack in the concrete. The specimen (Figure 4) was kept under the compressive load that applied on the column head of the specimen. The mid and edge (periphery) deflection were recorded till the ultimate load.

$$
\text { Shear Stress }\left(\tau_{c}\right)=\frac{P_{p}}{U 1 \times d} \text {, }
$$

where $P_{p}$ is ultimate slab loading capacity $(\mathrm{kN}), U 1$ is length of the perimeter at a distance " $2 d$ " from the loaded area, $d$ is effective depth of slab $(0.75 D)$, and $D$ is overall depth of slab.

3.3. Impact Test. The size of the test specimen was $400 \mathrm{~mm}$ in diameter and $40 \mathrm{~mm}$ thick. The load of $4.75 \mathrm{~kg}$ was dropped from the height of $0.5 \mathrm{~m}$ on the centre of the specimen. The number of blows was recorded for obtaining the first crack and ultimate failure. The first crack in the specimen occurred from the bottom which denotes the failure of concrete and the rest of the load till ultimate failure load was taken by the

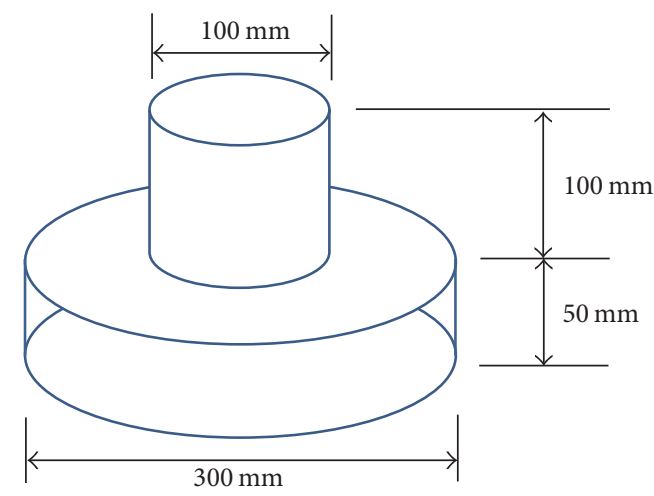

FIgURE 4: Specimen dimension.

fibre present in the specimen and the test setup is shown in Figure 5.

$$
\begin{aligned}
\text { Impact strength }= & (9.81 \times \text { load }) \times \text { height } \\
& \times \text { number of blows. }
\end{aligned}
$$

\section{Discussion}

4.1. Punching Shear Test. In the slag based geopolymer concrete, the addition of sodium hydroxide solution as the 


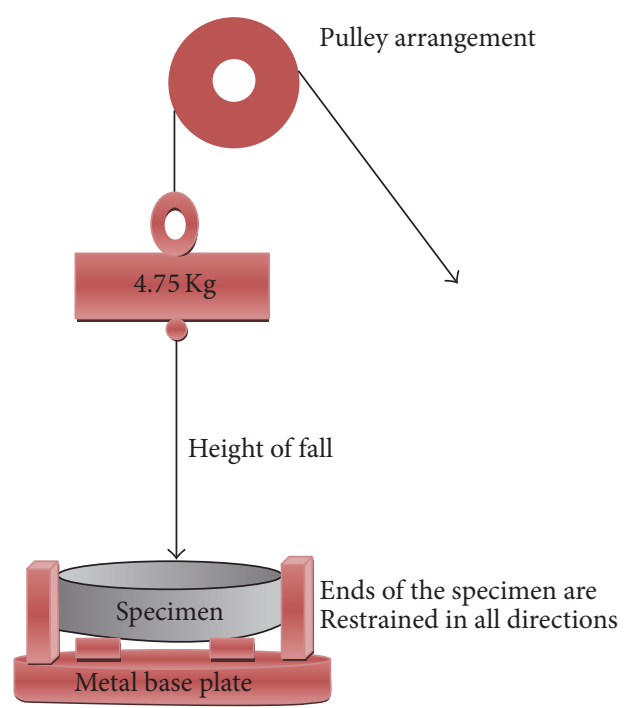

FIGURE 5: Setup of impact strength test for slag based geopolymer concrete.

alkali activator is enough for the geopolymerization reaction process for binding of concrete. The slag is having the enough amounts of silica and alumina in it. When the sodium hydroxide is mixed with binder the silica and alumina atoms present in the slag will dissolve by the hydrogen ions present in the solution. The chemical reaction taking place is called the polycondensation reaction leading to the 3-dimensional inorganic polymeric chain structure called Wollastonite. Wollastonite is also otherwise known as $\mathrm{CaSiO}_{3}$. The reaction is immediate which mixed with the slag. The inorganic polymeric chain will develop and get strong bind only with the heat environment. The physical representation of the polymerization reaction was identified by the change in colour of the slag paste from white to dark green. The physical change of chemical reaction is taking place in the slag which we can see very easily. After the polymerization chain reaction reaches its saturation level there will be gradual change of colour from dark green to dusty white.

The punching shear test was conducted on hardened slag based fibre reinforced geopolymer concrete specimen after curing. The specimen was kept over the hollow metallic ring like the slab resting on the ring and the load was applied on the column which is on the centre of the slab specimen as shown in Figure 4. The test was conducted in the digital compression machine of $2000 \mathrm{kN}$ capacity operated at a loading rate of $2.5 \mathrm{kN} / \mathrm{sec}$. The test specimen has a column head of size $100 \mathrm{~mm}$ in diameter and $100 \mathrm{~mm}$ height and circular slab of size $300 \mathrm{~mm}$ in diameter and $50 \mathrm{~mm}$ thickness; both slab and column are casted monolith.

The punching shear strength of the slag based geopolymer concrete reinforced with steel fibre was carried out and the dosage of steel fibre in slag based geopolymer concrete is shown in Table 5. The concrete mixtures GC2 $(\mathrm{B} / \mathrm{TA}=0.22$, $\mathrm{FA} / \mathrm{CA}=0.6)$ and $\mathrm{GC} 5(\mathrm{~B} / \mathrm{TA}=0.30, \mathrm{FA} / \mathrm{CA}=0.44)$ and steel fibre were reinforced in plain concrete for various percentages of 0.5, 1.0, and 1.5 (GCF21, GCF22 GCF23, GCF51, GCF52, and GCF53) and were tested. The specimens were prepared

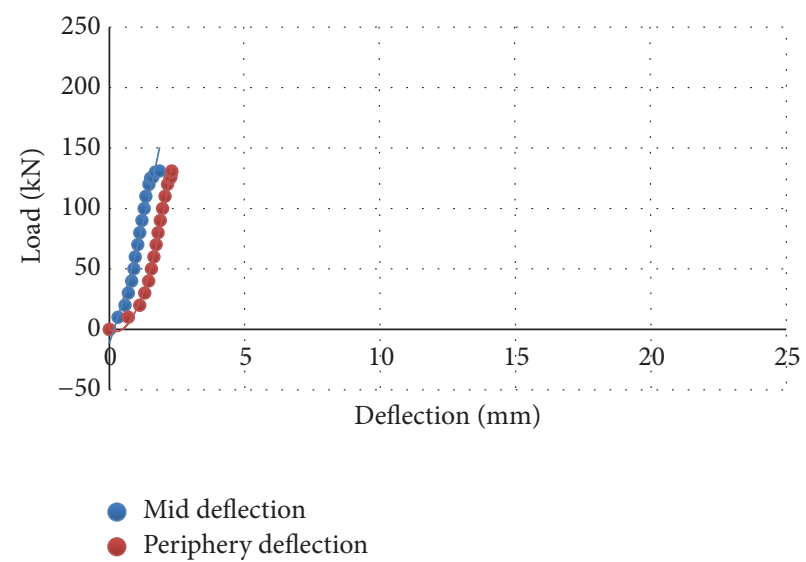

FIgURE 6: Punching shear values for control mix concrete (GC2).

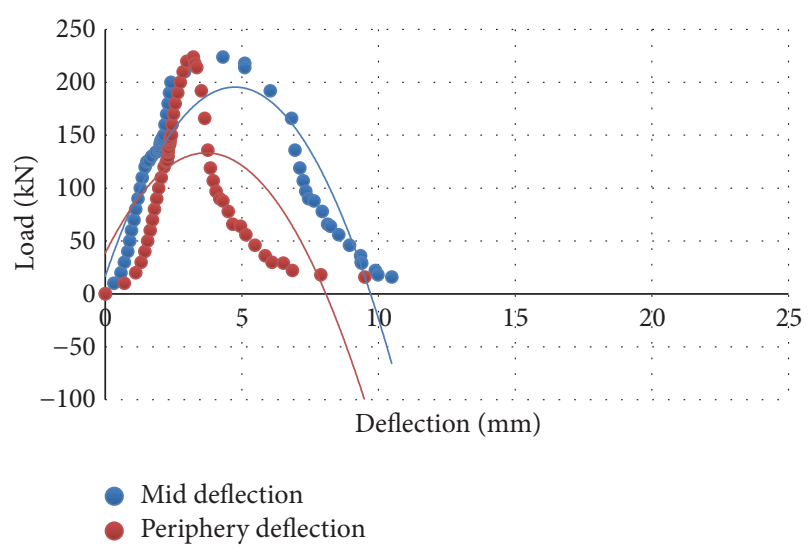

FIGURE 7: Punching shear values for $0.5 \%$ of steel fibre (GCF21).

as the slab-column junction for the size of column head of $100 \mathrm{~mm} \times 100 \mathrm{~mm}$ diameter and slab thickness of $50 \mathrm{~mm} \times$ $300 \mathrm{~mm}$ diameter. The samples were prepared for the control mixture and three various percentages of steel fibre.

The specimens were kept under the compressive load applied on the column head. The two dial gauges were used, and one was kept on the middle of the slab and another was kept at the edge periphery of the slab. When the load is applied on the column head, the sudden failure takes place in the slab. The ultimate load of the slab is shown in Table 6. The ultimate load for the control mix specimen (GC2) was $131.0 \mathrm{kN}$. In steel fibre reinforced concrete specimens, the ultimate load was increased to 1.75 times approximately less or more than the control concrete (without fibre). The concrete with $1.5 \%$ of steel fibre has attained the ultimate slab load of $234.0 \mathrm{kN}$. The shear mechanism was taking place in between column and slab when the load was applied on the column head. The shear stress was increased to double the times when compared with control mix ( $0 \%$ steel fibre) and steel fibre reinforced mix (1.5\% steel fibre). The control mix attained $5.2 \mathrm{~N} / \mathrm{mm}^{2}$ and $1.5 \%$ of steel fibre reinforced concrete attained $12.3 \mathrm{~N} / \mathrm{mm}^{2}$, shown in Table 6 and Figures 6-9. The steel fibre acts as a crack bridge to reduce the crack and the concrete was behaving as a ductile material in the shear face of the specimen which is slab-column junction. The sudden 
TABLE 5: Dosage of steel fibre in slag based geopolymer concrete.

\begin{tabular}{|c|c|c|c|c|c|c|c|c|c|c|c|}
\hline Mix ID & Slag & \multicolumn{2}{|c|}{$\left(\mathrm{kg} / \mathrm{m}^{3}\right)$} & SF & $\begin{array}{c}\text { Water } \\
\left(\mathrm{lit} / \mathrm{m}^{3}\right)\end{array}$ & $\begin{array}{c}\mathrm{NaOH} \\
(\mathrm{kg})\end{array}$ & B/TA & $\mathrm{FA} / \mathrm{CA}$ & $\mathrm{AC} / \mathrm{B}$ & $\mathrm{Ca} \mathrm{NO}$ & $\mathrm{Na}_{2} \mathrm{SO}_{4}$ \\
\hline GC2 & 425 & 720 & 1200 & 0 & 127.5 & 40.13 & 0.22 & 0.6 & 0.3 & 1.00 & 10 \\
\hline GCF21 & 425 & 720 & 1200 & 12 & 127.5 & 40.13 & 0.22 & 0.6 & 0.3 & 1.00 & 10 \\
\hline GCF22 & 425 & 720 & 1200 & 24 & 127.5 & 40.13 & 0.22 & 0.6 & 0.3 & 1.00 & 10 \\
\hline GCF23 & 425 & 720 & 1200 & 36 & 127.5 & 40.13 & 0.22 & 0.6 & 0.3 & 1.00 & 10 \\
\hline GC5 & 530 & 530 & 1200 & 0 & 159 & 50.04 & 0.30 & 0.44 & 0.3 & 1.00 & 10 \\
\hline GCF51 & 530 & 530 & 1200 & 12 & 159 & 50.04 & 0.30 & 0.44 & 0.3 & 1.00 & 10 \\
\hline GCF52 & 530 & 530 & 1200 & 24 & 159 & 50.04 & 0.30 & 0.44 & 0.3 & 1.00 & 10 \\
\hline GCF53 & 530 & 530 & 1200 & 36 & 159 & 50.04 & 0.30 & 0.44 & 0.3 & 1.00 & 10 \\
\hline
\end{tabular}

Note. GC: geopolymer concrete; GCF: geopolymer concrete with fibre; FA: fine aggregate; CA: coarse aggregate; SF: steel fibre; B/TA: binder to total aggregate; FA/CA: fine aggregate to course aggregate; $\mathrm{AC} / \mathrm{B}$ : accelerator to binder.

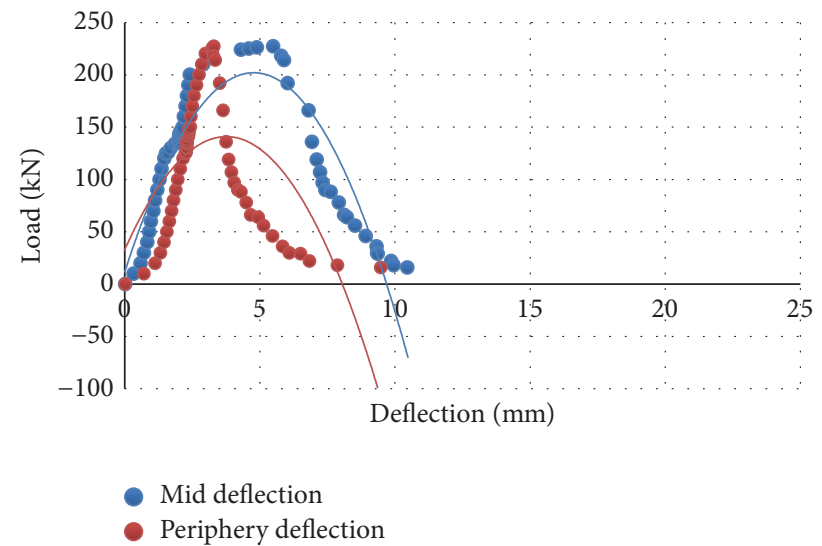

FIGURE 8: Punching shear values for 1.0\% of steel fibre (GCF22).

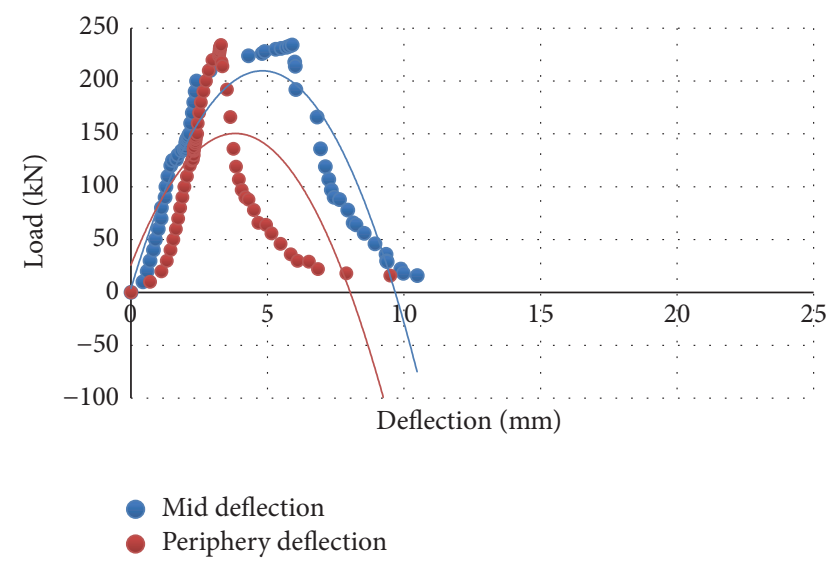

Figure 9: Punching shear values for 1.5\% of steel fibre (GCF23).

failure was restricted to gradual failure when the steel fibre was reinforced in concrete.

4.2. Impact Test. The slag based steel fire reinforced geopolymer concrete circular slabs are casted for the size of $50 \mathrm{~mm}$ thick and diameter of $400 \mathrm{~mm}$. The specimens are well cured and kept for the testing of impact strength. The circular slab specimen rested on the base plate which has the four
TABLE 6: Shear stress for various percentage of steel fibre and its ultimate load capacity.

\begin{tabular}{lccc}
\hline Mix ID & $\begin{array}{c}\text { Steel fibre } \\
(\%)\end{array}$ & $\begin{array}{c}\text { Shear stress }\left(\tau_{c}\right) \\
\left(\mathrm{N} / \mathrm{mm}^{2}\right)\end{array}$ & $\begin{array}{c}\text { Ultimate slab loading }\left(P_{p}\right) \\
(\mathrm{kN})\end{array}$ \\
\hline GC2 & 0.0 & 5.2 & 131 \\
GCF21 & 0.5 & 11.8 & 224 \\
GCF22 & 1.0 & 11.9 & 227 \\
GCF23 & 1.5 & 12.3 & 234 \\
GC5 & 0.0 & 4.5 & 115 \\
GCF51 & 0.5 & 9.7 & 184 \\
GCF52 & 1.0 & 10.1 & 192 \\
GCF53 & 1.5 & 10.5 & 200 \\
\hline
\end{tabular}

supports on the four sides. The slab was well tightened with the base plate by the side screws. The $4.75 \mathrm{~kg}$ weight is tied with the rope which is dropped from $0.5 \mathrm{~m}$ height which is the fall of height at the middle point of the slag based steel fibre reinforced geopolymer concrete slab by using the pulley arrangement. The number blows were counted till the specimen fails [13].

(i) First crack toughness was measured by seeing the crack on the slag and it occurs from the bottom of the slab. It means the failure of the concrete system. For without fibre first crack is the ultimate load.

(ii) Ultimate failure toughness is the entire collapse of the fibre reinforced geopolymer concrete after several blows.

(iii) Postpeak toughness is defined as ratio of ultimate failure toughness by first crack toughness.

(iv) Increase in toughness is defined as an increase in value of steel fibre reinforced geopolymer concrete to the control geopolymer concrete.

The performance of the steel fibre in the slag based geopolymer concrete was also evaluated. The concrete mix GC2 $(\mathrm{B} / \mathrm{TA}=0.22$ and $\mathrm{FA} / \mathrm{CA}=0.6)$ was tested with three various percentages of steel fibres like 0.5, 1.0, and 1.5 (GC21, GC22, and GC23). The test specimens were cast in the circular shape of diameter of $400 \mathrm{~mm}$ and thickness of $40 \mathrm{~mm}$. The setup 


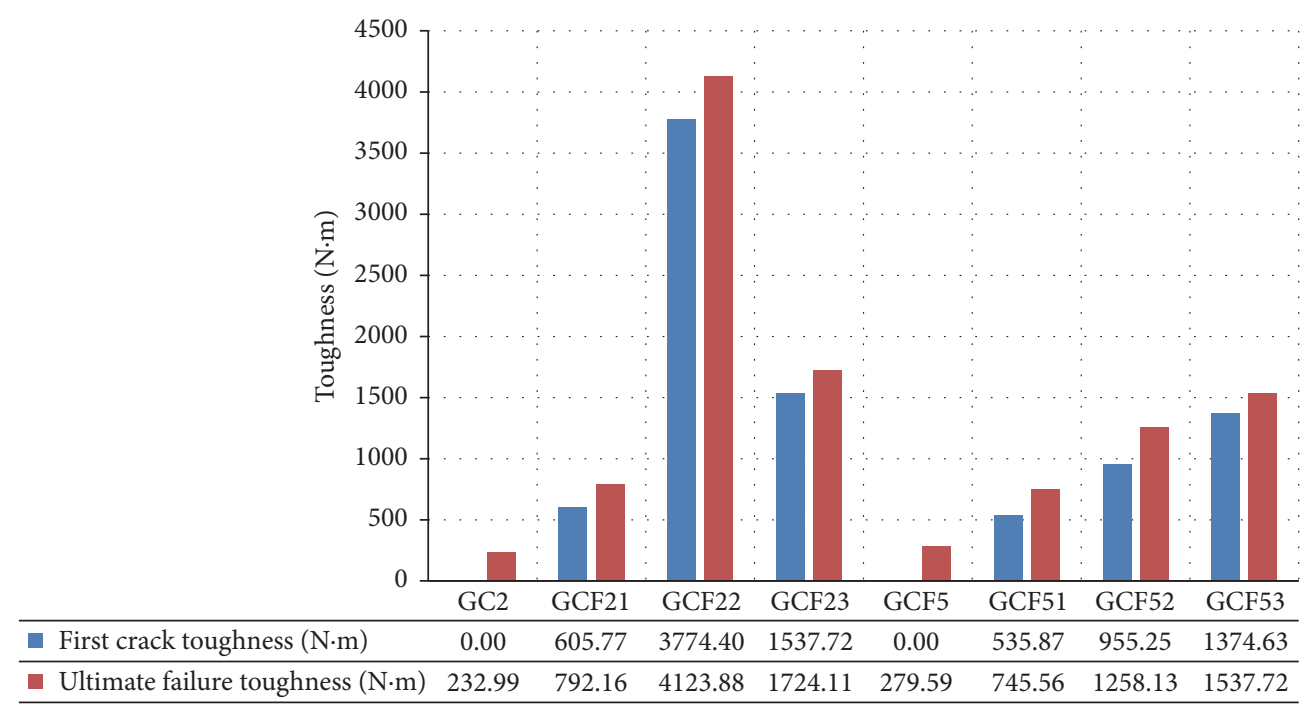

FIGURE 10: Impact toughness strength test for slag based geopolymer concrete with various percentage of steel fibre (Mix-GC2, GCF21, GCF22, and GCF23).

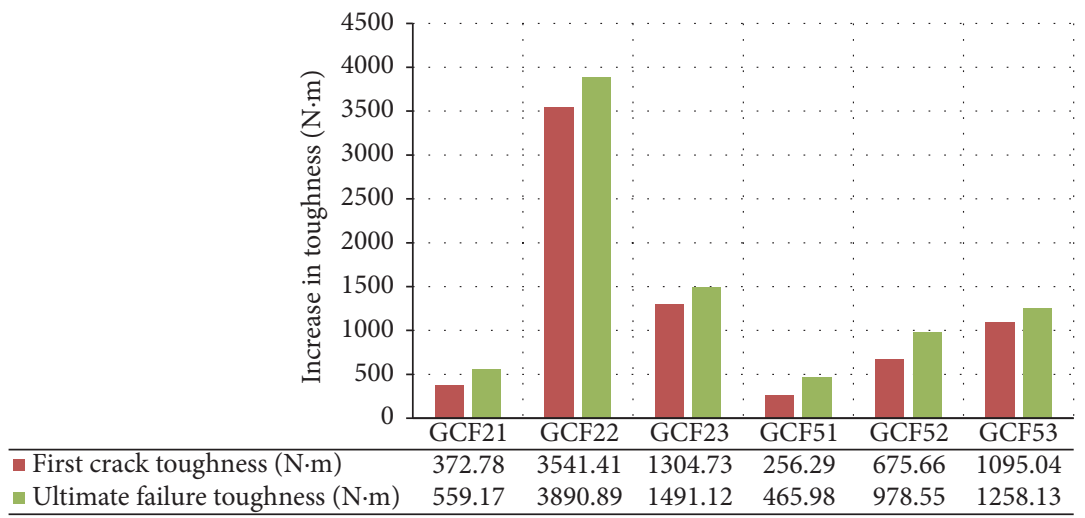

FIGURE 11: Increase in toughness of fibre reinforced geopolymer concrete to its reference concrete (GCF21, GCF22, and GCF23).

was arranged for the test, and the samples were clamped in the baseplate and load of $4.75 \mathrm{~kg}$ was dropped from the height of $0.5 \mathrm{~m}$ on the centre of the specimen (Figure 5). The numbers of blows were recorded when first crack formed in specimen as well as for ultimate failure of specimen. The first crack in specimen clearly indicates that ultimate failure load was reached by concrete and the rest of the impact load was absorbed by the specimen till its failure was taken by steel fibres in concrete [13]. In the controlled mix (GC2, without fibres), the impact load was applied on the specimen which absorbed the energy. The first crack was formed after the several impact loads on the specimen and the first crack started from the soffit of the slab. The first crack toughness was the same as ultimate failure toughness of $232.9 \mathrm{~N} \cdot \mathrm{m}$. But in the fibre reinforced concrete samples when the first crack was formed, the number of blows was counted (Table 6), and toughness was calculated in Table 7.

The first crack toughness and ultimate failure toughness were calculated for all the remaining three mixtures and are shown in Figures 10-12. After several blows on the same sample, it was able to withstand the load till the fibre failure and losing the intactness between the concrete matrixes. The higher fibre content also affected the energy absorption of the concrete that can be seen in the mix GCF23 $(1.5 \%$ of steel fibres reinforced concrete).

The postpeak toughness was also done by first crack toughness-ultimate failure toughness of the steel fibre reinforced concrete specimens as shown in Figure 12.

$$
\begin{aligned}
\text { Impact strength }= & (9.81 * \text { load }) * \text { height } \\
& * \text { number of blows. }
\end{aligned}
$$

\section{Conclusions}

The experiments were carried out in the steel fibre reinforced slag based geopolymer concrete for finding out the mechanical properties and performance of slag and steel fibres. The presence of Wollastonite in concrete was persistently observed in SEM and EDX analysis. The performance of the steel fibre in the slag based geopolymer concrete was also evaluated by conducting tests like punching shear and 
TABLE 7: Total number of blows for various percentage of steel fibre in concrete.

\begin{tabular}{|c|c|c|c|c|}
\hline Mix ID & GC2 (reference) & GCF21 & GCF22 & GCF23 \\
\hline Steel fibre (\%) & 0.0 & 0.5 & 1.0 & 1.5 \\
\hline Number of blows for initial crack formation & 10 & 26 & 162 & 66 \\
\hline Number of blows for ultimate failure & - & 34 & 177 & 74 \\
\hline
\end{tabular}

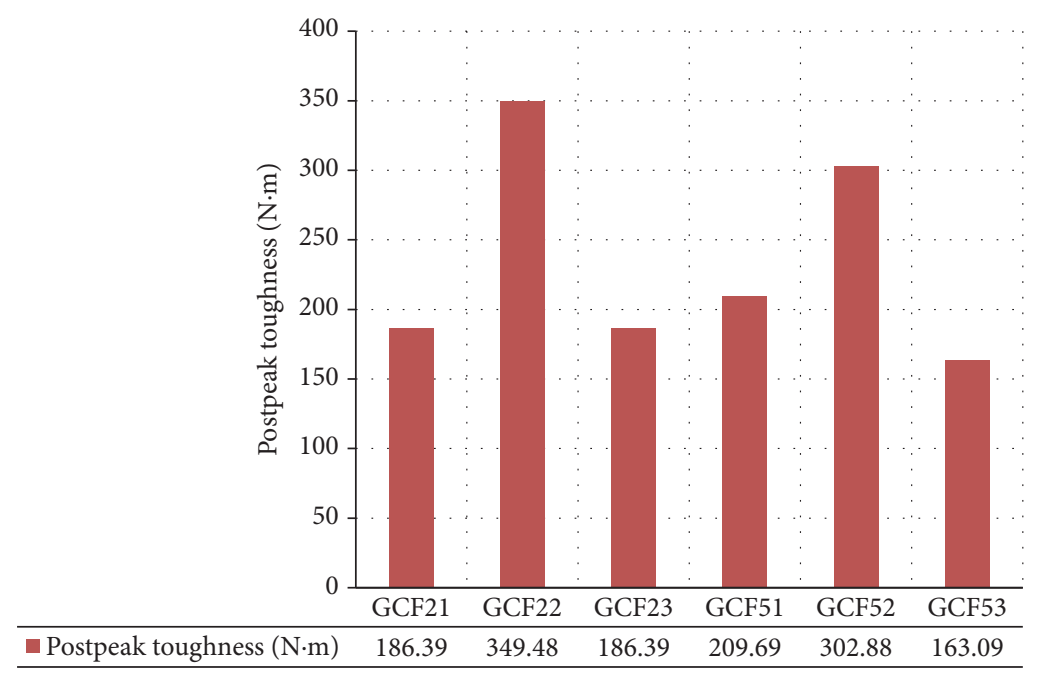

FIGURE 12: Postpeak toughness of each percentage of fibre reinforced geopolymer concrete (GCF21, GCF22, and GCF23).

impact test. From the observations the concrete mix ratio of GCF22 (binder to total aggregate ratio of 0.22 and fine to coarse aggregate ratio of 0.6 with $1.0 \%$ of steel fibre) was showing the better performance; in punching shear the stress was $11.9 \mathrm{~N} / \mathrm{mm}^{2}$ and in impact test the energy absorption of mixture GCF22 shows $3541.41 \mathrm{~N} \cdot \mathrm{m}$ in increase in toughness of first crack and $349.48 \mathrm{~N} \cdot \mathrm{m}$ in postpeak toughness. So it is observed that $1.0 \%$ of steel fibre is optimised and mixture GCF22 is suggested to be better in shear and energy absorption.

\section{Conflicts of Interest}

The author declares that there are no conflicts of interest regarding the publication of this paper.

\section{References}

[1] C. Menna, D. Asprone, C. Ferone et al., "Use of geopolymers for composite external reinforcement of RC members," Composites Part B: Engineering, vol. 45, no. 1, pp. 1667-1676, 2013.

[2] D. M. Bastidas, A. Fernández-Jiménez, A. Palomo, and J. A. González, "A study on the passive state stability of steel embedded in activated fly ash mortars," Corrosion Science, vol. 50, no. 4, pp. 1058-1065, 2008.

[3] E. Cailleux, T. Cutard, and G. Bernhart, "Pullout of steel fibres from a refractory castable: experiment and modelling," Mechanics of Materials, vol. 37, no. 4, pp. 427-445, 2005.

[4] H. Su, J. Xu, and W. Ren, "Mechanical properties of ceramic fiber-reinforced concrete under quasi-static and dynamic compression," Materials and Design, vol. 57, pp. 426-434, 2014.
[5] M. Saafi, K. Andrew, P. L. Tang et al., "Multifunctional properties of carbon nanotube/fly ash geopolymeric nanocomposites," Construction and Building Materials, vol. 49, pp. 46-55, 2013.

[6] S. Vaidya and E. N. Allouche, "Strain sensing of carbon fiber reinforced geopolymer concrete," Materials and Structures, vol. 44, no. 8, pp. 1467-1475, 2011.

[7] T. Alomayri and I. M. Low, "Synthesis and characterization of mechanical properties in cotton fibre-reinforced geopolymer composites," Journal of Asian Ceramic Societies, vol. 1, no. 1, pp. 30-34, 2013.

[8] Z. Yunsheng, S. Wei, and L. Zongjin, "Impact behavior and microstructural characteristics of PVA fiber reinforced fly ashgeopolymer boards prepared by extrusion technique," Journal of Materials Science, vol. 41, no. 10, pp. 2787-2794, 2006.

[9] A. Nazari, A. Maghsoudpour, and J. G. Sanjayan, "Flexural strength of plain and fibre-reinforced boroaluminosilicate geopolymer," Construction and Building Materials, vol. 76, pp. 207-213, 2015.

[10] H. Ju, K. S. Kim, D. H. Lee, J.-H. Hwang, S.-H. Choi, and Y.$\mathrm{H}$. Oh, "Torsional responses of steel fiber-reinforced concrete members," Composite Structures, vol. 129, pp. 143-156, 2015.

[11] F. Liu, G. Chen, L. Li, and Y. Guo, "Study of impact performance of rubber reinforced concrete," Construction and Building Materials, vol. 36, pp. 604-616, 2012.

[12] H. Su and J. Xu, "Dynamic compressive behavior of ceramic fiber reinforced concrete under impact load," Construction and Building Materials, vol. 45, pp. 306-313, 2013.

[13] T. Rahmani, B. Kiani, M. Shekarchi, and A. Safari, "Statistical and experimental analysis on the behavior of fiber reinforced concretes subjected to drop weight test," Construction and Building Materials, vol. 37, pp. 360-369, 2012.

[14] W. H. Kwan, M. Ramli, and C. B. Cheah, "Flexural strength and impact resistance study of fibre reinforced concrete in simulated 
aggressive environment," Construction and Building Materials, vol. 63, pp. 62-71, 2014.

[15] W. Li and J. Xu, "Mechanical properties of basalt fiber reinforced geopolymeric concrete under impact loading," Materials Science and Engineering A, vol. 505, no. 1-2, pp. 178-186, 2009.

[16] British Standard, "Specification for Ground granulated blast furnace slag for use with Portland cement," BS 6699-1992, British Standard, London, UK, 1992.

[17] IS, "Indian standard specification for coarse and fine aggregates from natural sources for concrete," IS 383-1970, Bureau of Indian Standards, New Delhi, India, 1997. 


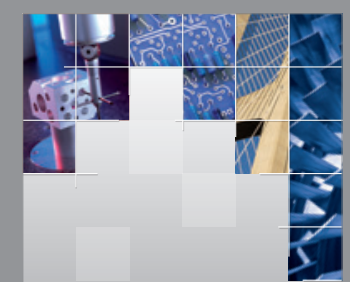

\section{Enfincering}
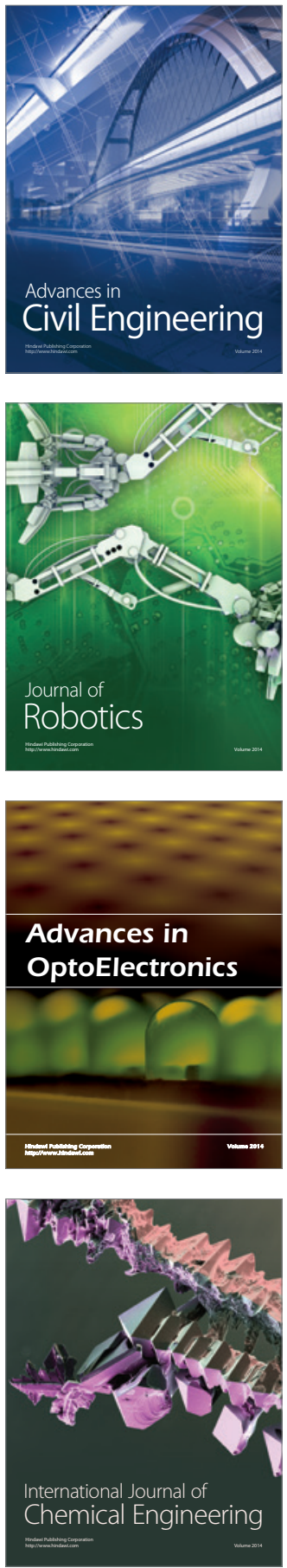

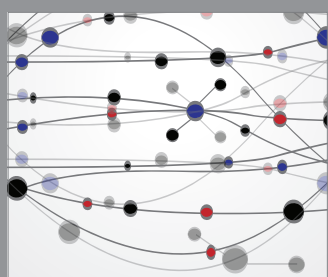

The Scientific World Journal

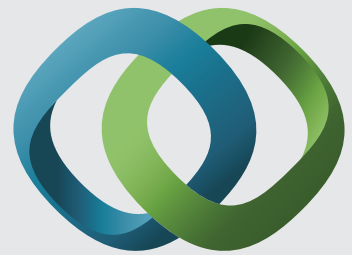

\section{Hindawi}

Submit your manuscripts at

https://www.hindawi.com
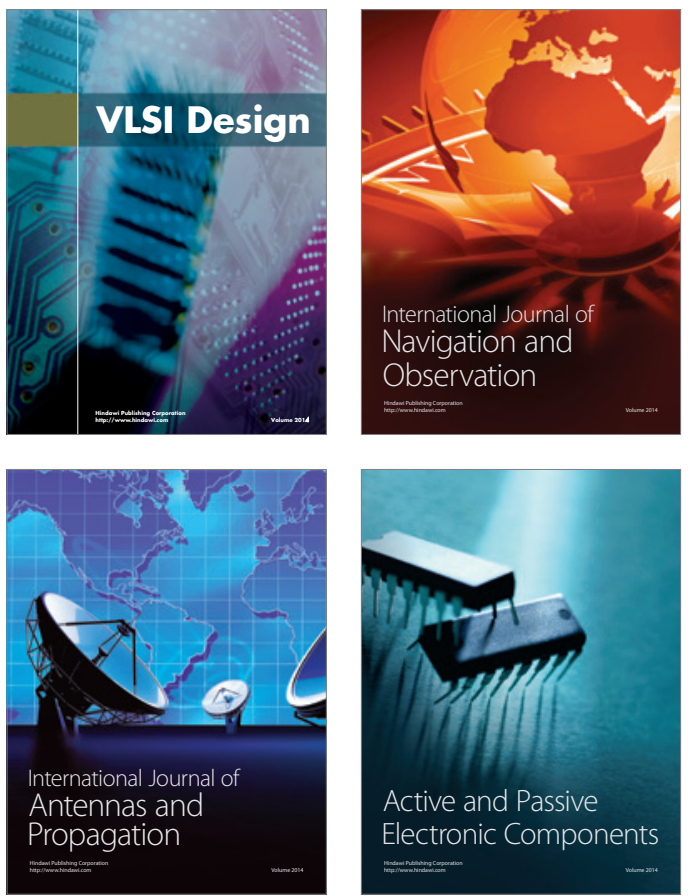
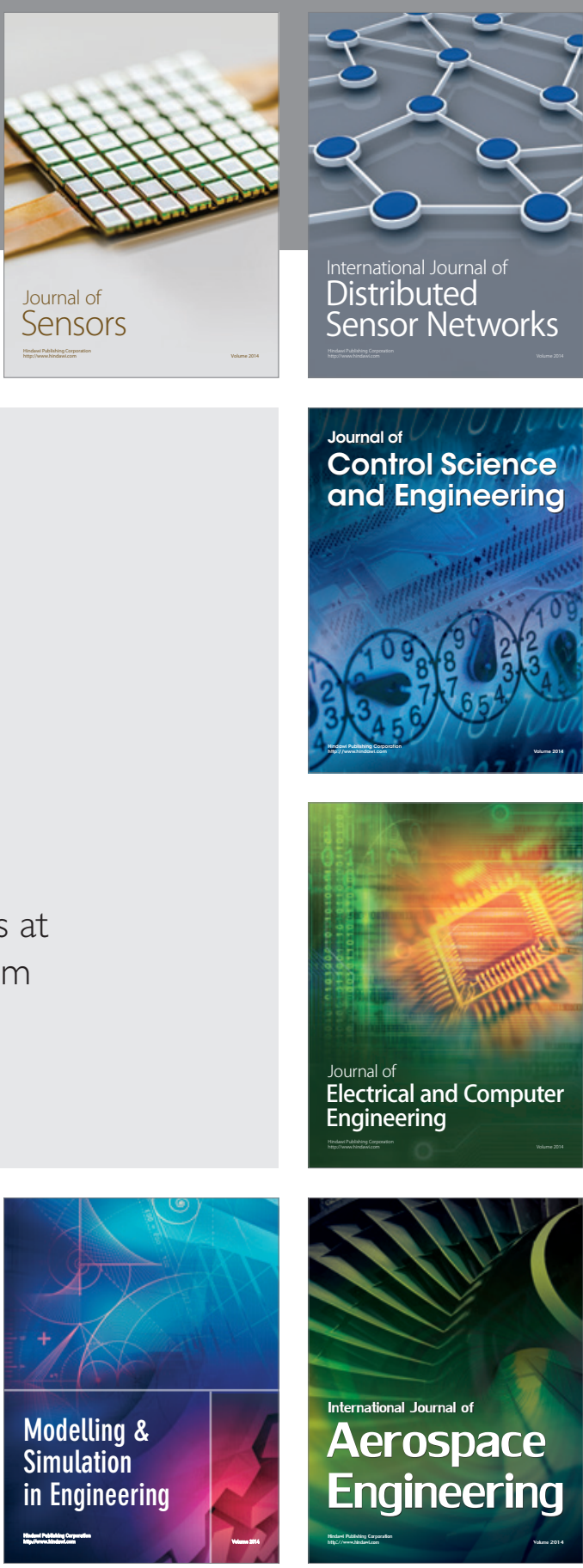

International Journal of

Distributed

Sensor Networks

$-$

Joumal of

Control Science

and Engineering
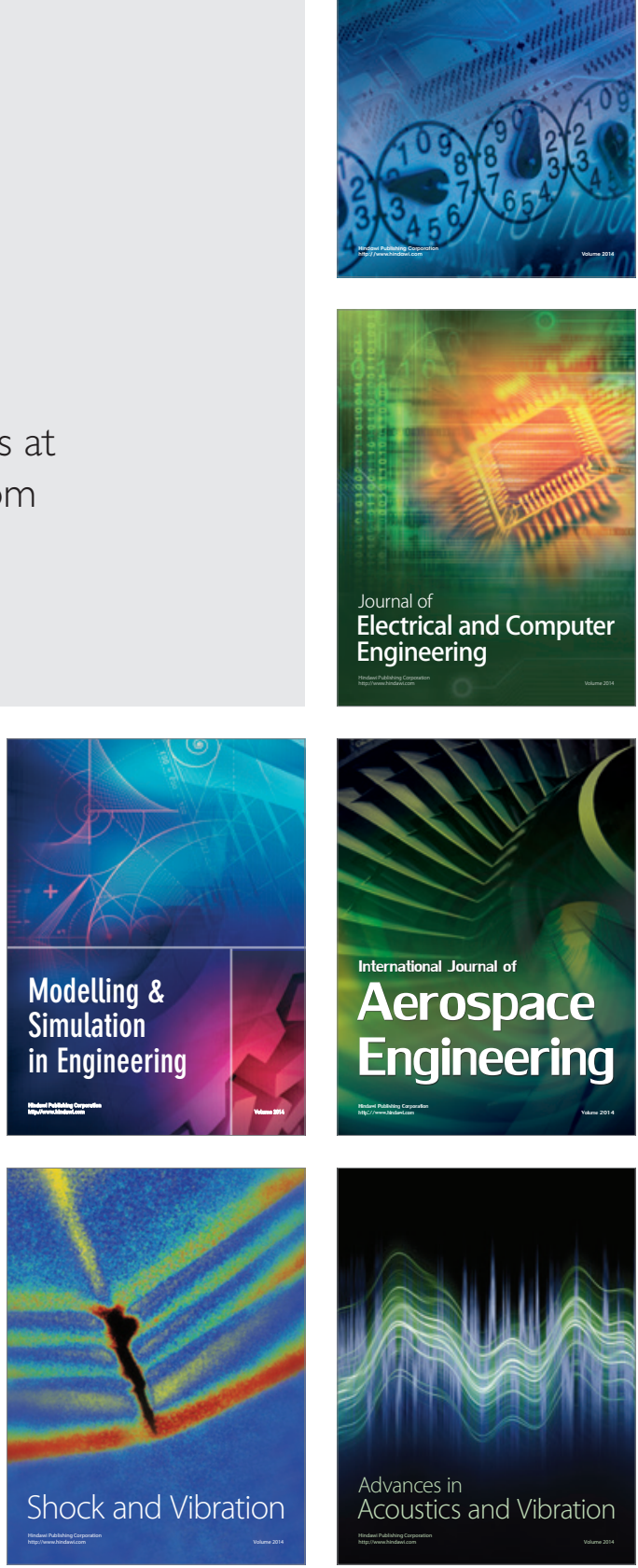